\title{
Allelic Variants of Glutamine Synthetase and Glutamate Synthase Genes in a Collection of Durum Wheat and Association with Grain Protein Content
}

\author{
Domenica Nigro ${ }^{1}$, Stefania Fortunato ${ }^{1}$, Stefania Lucia Giove ${ }^{2}$, Giacomo Mangini ${ }^{1}$, \\ Ines Yacoubi ${ }^{3}$, Rosanna Simeone ${ }^{1}$, Antonio Blanco ${ }^{1}$ and Agata Gadaleta ${ }^{2, *}$ \\ 1 Department of Soil, Plant \& Food Sciences, Plant Breeding Section, University of Bari Aldo Moro, \\ Via Amendola, 165/a, 70126 Bari BA, Italy; domenica.nigro@uniba.it (D.N.); \\ stefania.fortunato26@gmail.com (S.F.); giacomo.mangini@uniba.it (G.M.); rosanna.simeone@uniba.it (R.S.); \\ antonio.blanco@uniba.it (A.B.) \\ 2 Department of Agricultural \& Environmental Science, University of Bari Aldo Moro, Via Amendola, 165/a, \\ 70126 Bari BA, Italy; s.giove1@inwind.it \\ 3 Biotechnology and plant improvement laboratory, Biotechnology Centre of Sfax Tunisia, Kef 7119, Tunisia; \\ ines.bouchrityaccoubi@cbs.rnrt.tn \\ * Correspondence: agata.gadaleta@uniba.it
}

Received: 6 October 2017; Accepted: 7 November 2017; Published: 16 November 2017

\begin{abstract}
Wheat is one of the most important crops grown worldwide. Despite the fact that it accounts for only $5 \%$ of the global wheat production, durum wheat (Triticum turgidum L. subsp. durum) is a commercially important tetraploid wheat species, which originated and diversified in the Mediterranean basin. In this work, the candidate gene approach has been applied in a collection of durum wheat genotypes; allelic variants of genes glutamine synthetase (GS2) and glutamate synthase (GOGAT) were screened and correlated with grain protein content (GPC). Natural populations and collections of germplasms are quite suitable for this approach, as molecular polymorphisms close to a locus with evident phenotypic effects may be closely associated with their character, providing a better physical resolution than genetic mapping using ad hoc constituted populations. A number of allelic variants were detected both for GS2 and GOGAT genes, and regression analysis demonstrated that some variations are positively and significantly related to the GPC effect. Additionally, these genes map into homoeologous chromosome groups 2 and 3, where several authors have localized important quantitative trait loci (QTLs) for GPC. The information outlined in this work could be useful in breeding and marker-assisted selection programs.
\end{abstract}

Keywords: durum wheat; genetic diversity; grain protein content; glutamine synthetase; glutamate synthase

\section{Introduction}

Wheat, together with rice and maize, is one the most important cereal crops grown worldwide. Most of the cultivated cultivars and varieties belong to the hexaploid Triticum aestivum L. (genomes AABBDD, bread wheat) or to the tetraploid T. turgidum L. var. durum (genomes AABB, durum wheat), which are different in genome size (bread wheat also having a D genome), grain composition, and food end-use quality attributes. Several agronomic traits and composition aspects determine the final quality of grains.

Among them, grain protein content (GPC) contributes to the nutritional value and the baking properties of common wheat and to the pasta-making technology characteristics of durum wheat. GPC is a quantitative trait influenced by a complex genetic system and affected by environmental factors as well as by management practices. Indeed, one of the most pursued goals of breeders 
in the last decades has been the improving of grain protein concentration. However, because of the negative correlation between grain yield and GPC, simultaneous increases of both traits have been difficult to achieve [1,2]. Nitrogen fertilizers are today extensively used to increase both crop yield and protein content. The current agricultural system requires growers to optimize the use of nitrogen fertilizers to avoid pollution, while maintaining reasonable profit margins. Numerous studies allowed the identification of candidate genes that encode enzymes involved in nitrogen assimilation and recycling [3], and many of them co-localized with agronomic and physiological traits related to nitrogen metabolism $[4,5]$. Two genes resulted to be particularly important in the first step of ammonia assimilation: glutamine synthetase and glutamate synthase. These two enzymes work synergistically in a cycle known as GS-GOGAT shunt, involved in the first step of $\mathrm{N}$ metabolism and glutamate synthesis.

The glutamine synthetase (GS) enzyme has an essential role in the assimilation and re-assimilation of inorganic N. GS genes represent a gene family with three to five isoforms, depending on the species [6]. On the bases of phylogenetic studies and mapping data in wheat, 10 GS cDNA sequences were classified into four sub-families denominated GS1 (a, b and c), GSr (1 and 2), GSe (1 and 2), active in cytosol, and GS2 (a, b and c), localized in plastids [7,8]. Several studies have been carried out on various isoforms as candidates for improving nitrogen use efficiency (NUE) in wheat, and their relationships with GPC have been investigated [8-12]. Once glutamine is synthetized, another important enzyme is involved in the second step of the reaction to the synthesis of glutamate: the glutamate synthase (Glutamine-2-oxoglutarate amidotransferase). This enzyme is responsible for the transfer of the amide group of glutamine to 2-oxoglutarate, with the result of two yielded glutamate molecules, one of which is then available for aminoacid synthesis and the other of which returns to the GS-GOGAT cycle [13]., Gene regulation, as well asenzymes structure, have been reported in previous works $[4,14]$. Based on the electron donors, GOGAT exists in plants in two different isoforms: A ferredoxin (Fd)-dependent (EC 1.4.7.1) form and an NADH-dependent (EC 1.4.1.14) form, both of which are located in plastids but in two different types of tissues. The Fd-GOGAT enzyme is usually present in photosynthesizing tissues, while the NADH-GOGAT enzyme is the predominant form in non-photosynthesizing cells. These differences in tissue location and enzyme roles have been well studied in both rice and conifers $[15,16]$. Additionally, mutagenesis studies showed that mutated and/or silenced GOGAT not only reduced enzyme activity but also seemed to be involved in changes in aminoacid metabolism [17-20].

Only a few studies have reported gene isolation and sequencing of GOGAT genes in plants, probably due to their length and structural complexity. GOGAT genes genomic sequences have been reported for maize [21], tobacco [22], Arabidopsis [23] and barley [24] and partial sequences were also reported in bread wheat [25]. Recently, NADH and Fd-GOGAT gene structures, genomic sequences, gene localization, and involvement in GPC control have been reported in durum wheat $[26,27]$.

Considering the importance and central role of these two genes in nitrogen metabolism, the main objectives of this study were to investigate the presence of allelic variants of both the plastidic GS2 and the GOGAT genes in a collection of tetraploid wheat genotypes and to validate the relationships between variants and GPC.

\section{Materials and Methods}

\subsection{Plant Material}

A collection of 236 tetraploid wheat genotypes (Triticum turgidum), including wild and cultivated accessions of seven subspecies (durum, turanicum, polonicum, turgidum, carthlicum, dicoccum and dicoccoides), was screened for GS2 and GOGAT allelic variants (List of accessions is reported in Table S3). The collection was bred in an experimental field of the University of Bari at Valenzano (Bari, Italy) in 2009 and 2010 and in Foggia (Italy) in 2009 in a randomized complete block design study with three replications. Each plot consisted of $1 \mathrm{~m}$ rows, $30 \mathrm{~cm}$ apart, and the seeding rate was 50 seeds per plot. 
Genomic DNA was isolated from fresh leaves and subsequently purified using a method previously described [28] and subsequently purified via phenol-chloroform extraction.

\subsection{PCR Condition and Sequencing}

PCR reactions were performed in final volumes of $20 \mu \mathrm{L}$ in BIORAD thermo cyclers. The reaction mixture contained each deoxynucleotide in $200 \mu \mathrm{M}$ concentrations, each primer in $0.5 \mu \mathrm{M}$ concentrations, $1 \times$ buffer, $0.02 \mathrm{U} / \mu \mathrm{L}$ Taq polymerase (Phusion High-Fidelity DNA Polymerase, Thermo Fisher Scientific, Waltham, MA, USA), and 50 ng of template DNA. Using Oligo Explorer software, a set of genome specific primer pairs were designed for GS2 and GOGAT genes, as reported in Tables S1 and S2. PCR fragments were purified with a QIAquick PCR purification kit (Qiagen, Hilden, Germany) cloned into the pCR4-TOPO vector (Invitrogen, Cloning Kit, Thermo Fisher Scientific, Waltham, MA, USA) following the manufacturer's instructions, and subsequently sequenced (3500 Genetic Analyzer, Applied Biosystem, Foster City, CA, USA). Sequences alignments were carried out using ClustalOmega (http://www.ebi.ac.uk/Tools/msa/clustalo/) and CodonCode Aligner software (CodonCode Corporation, Centerville, MA, USA).

\subsection{Digestion with CEL I and Revelation Fragments}

In order to discover mutations within GOGAT gene sequences in the durum wheat collection previously described, single nucleotide polymorphisms (SNPs) were detected using the Surveyor nuclease kit (Transgenomic, Omaha, NE, USA). Heteroduplex formation, CelI digestion and gel analysis were performed following a procedure previously reported [27].

\subsection{Protein Content Quantification and Regression Analysis}

Grain protein content (GPC) and yield components were evaluated in the durum wheat collection previously described grown in three different environments. GPC was assessed on $3 \mathrm{~g}$ of whole meal flour using a dual beam near infrared reflectance spectrophotometer (Zeutec Spectra Alyzer Premium, Zeutec Büchi, Rendsburg, Germany). Linear regression analysis between each allelic variant of both GS and GOGAT genes and GPC were carried out using MSTAT-C software developed by Freed et al. [29], Michigan State University.

\section{Results and Discussion}

\subsection{Phenotypic Characterization for the Protein Content of a Collection of Tetraploid Wheat Genotypes}

A collection of 236 tetraploid wheats genotypes, including durum cultivars, landraces, and wild accessions, has been characterized in terms of genetic diversity and population structure [30] and used for genome-wide association mapping of loci controlling some qualitative important traits, such as $\beta$-glucan content [31], carotenoid content [32] and phenolic acids [33]. GPC was determined in three replicated field experiments. Table 1 shows the summary data of protein content expressed as grams of protein on $100 \mathrm{~g}$ of dry weight of wholegrain. Variance analysis revealed significant differences between genotypes $(p<0.001)$.

Table 1. Mean, standard deviation (SD), ranges, and coefficient of variation (CV \%) of grain protein content (GPC) ( $\mu \mathrm{g} / \mathrm{g}$ dry matter) in a tetraploid wheat collection evaluated in three different environments.

\begin{tabular}{cccc}
\hline Environment & Foggia 2009 & Valenzano 2009 & Valenzano 2010 \\
\hline Mean & 14.1 & 16.2 & 15.5 \\
SD & 1.55 & 2.01 & 2.21 \\
Min & 10.8 & 11.8 & 12.5 \\
Max & 20.4 & 22.9 & 23.5 \\
CV $(\%)$ & 10.9 & 12.4 & 14.3 \\
\hline
\end{tabular}


The highest GPC mean value (16.2\%) was found for the trial of Valenzano 2009; however, looking at the three trials, minimum and maximum values ranged from 10.8 and 23.5, respectively. Additionally, the coefficient of variation showed different values among the trials, ranging from 10.9 to 14.3. Variance analysis revealed significant differences in $p<0.001$ between genotypes.

\subsection{GS2 Allelic Variants and Relationship with GPC}

Based on the genomic sequences of the two homoeologous genes GS2-2A and GS2-2B previous isolated [10], several pairs of specific genomic primers reported in Table S1 were drawn. These were amplified and screened for genomic variations in the entire collection of tetraploid wheat (see Materials and Methods).

Three major polymorphisms were found in the GS2 gene. An insertion/deletion of a $239 \mathrm{bp}$ MITE (Miniature Inverted-Repeat Transposable Element), located in the second intron of the 2A homoelogous chromosome, identifies the only allelic variant for the GS2-2A gene. Out of the analyzed 236 wheat genotypes, the intronic Miniature Inverted Transposable Element was found in 96 genotypes. On the other hand, two different polymorphisms were identified on the $2 \mathrm{~B}$ homoelogous chromosome: a repeated $5 \mathrm{bp}$ microsatellite (GATTA) and a $33 \mathrm{bp}$ indel, respectively, located in the first and second introns of the GS2-2B gene. Figure 1 shows peaks corresponding to MITE deletion in the second intron of the GS2-2A gene (peak at $480 \mathrm{bp}$, and the $33 \mathrm{bp}$ deletion/insertion of the GS2-2B gene (473 and $507 \mathrm{bp}$, respectively) [10].
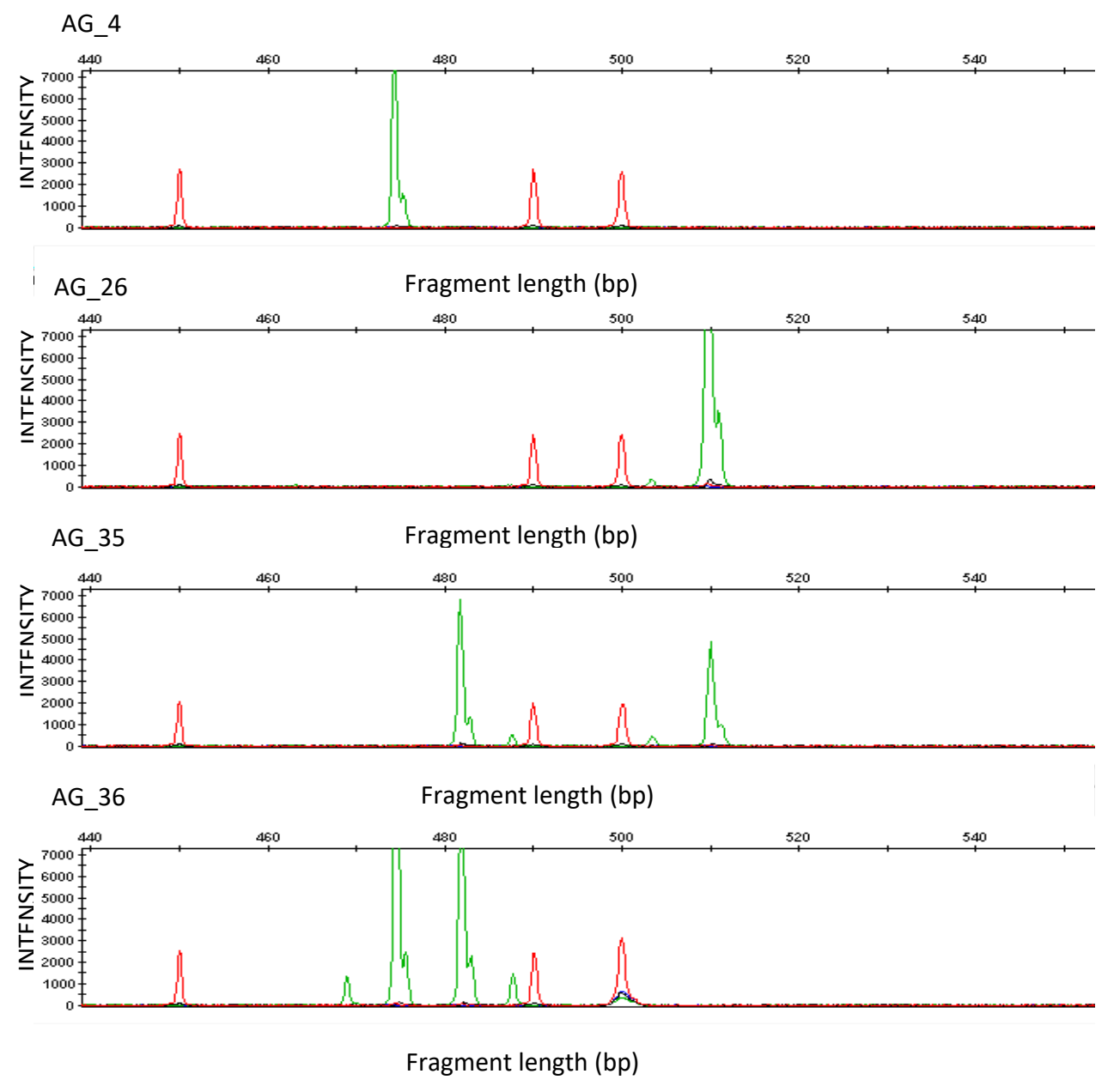

Figure 1. Polymorphisms detected in the GS2 genes in genotypes of the durum collection. Peaks corresponding to MITE deletion in the second intron of the GS2-2A gene (peak at $480 \mathrm{bp}$ ) and the $33 \mathrm{bp}$ deletion/insertion of the GS2-2B gene ( 473 and $507 \mathrm{bp}$, respectively) are shown. 
We ran a regression analysis between the GS2 allelic variants and the GPC in the described tetraploid wheat collection evaluated in three replicated field experiments. The regression analysis with the GS2-A2 alleles showed that the amplicon of $480 \mathrm{bp}$ absent of MITE is positively correlated with GPC in all three environments (Table 2). The stronger correlation was found in the Foggia 2009 environment $(p \geq 0.001)$, while the lowest one, albeit still significant at $p \geq 0.05$, was found in Valenzano 2009. The phenotypic variation ranged from 4.1 to $9.2 \%$. Although significant results were previously reported [10], no significant correlation was instead outlined by the regression analysis between GPC and the $33 \mathrm{bp}$ indel of the GS2-B2 gene, likely due to the fact that an unequal distribution of alleles occur in the collection of genotypes.

Table 2. Regression analysis between GS2 allelic variants and GPC $\left(\% \mathrm{DW}^{-1}\right)$ in a tetraploid wheat collection evaluated in three replicated field experiments.

\begin{tabular}{|c|c|c|c|c|c|c|c|c|c|c|c|}
\hline \multirow{3}{*}{ Gene } & \multirow{3}{*}{ Amplicons (bp) } & \multirow{3}{*}{ Frequency } & \multicolumn{9}{|c|}{ Environments } \\
\hline & & & \multicolumn{3}{|c|}{ Foggia 2009} & \multicolumn{3}{|c|}{ Valenzano 2009} & \multicolumn{3}{|c|}{ Valenzano 2010} \\
\hline & & & $\log _{10}(p)$ & Effect & $R^{2}$ & $\log _{10}(p)$ & Effect & $R^{2}$ & $-\log _{10}(p)$ & Effect & $R^{2}$ \\
\hline GS2-A2 & $480 / 719$ & $131-90$ & $5.3^{* * *}$ & 0.92 & 9.2 & $2.6 *$ & 0.83 & 4.1 & $3.7^{* *}$ & 1.11 & 6.1 \\
\hline GS2-B2 & $473 / 507$ & $184-37$ & 0.4 & 0.24 & 0.4 & 0.4 & -0.33 & 0.4 & 0.1 & 0.13 & 0.0 \\
\hline
\end{tabular}

Glutamine synthetase plays a key role in the use of absorbed nitrogen, process of primary importance for plant growth. The absorption and utilization of nitrogen are closely related both to production and to the accumulation of grain proteins in various cereal species. Haplotype analysis of GS2 gene and their association with NUE and yield-related traits was performed in bread wheat [34]. MITE was also found in Chinese bread wheat genotypes, and an interesting association with yield-related traits was also found.

Recently, a genome-wide association analysis with high-density SNP markers was conducted in order to identify genomic regions that may be associated with NUE traits in Great Plains hard winter wheat germplasm [35]. Interestingly, it was found that SNP markers on the long arm of a 2D chromosome were associated with NUE traits, in the same distal position where GS2 genes map.

Other authors reported a colocalization between GS genes and GPC quantitative trait loci (QTLs) in a DHL population in three different environments [36]. A Meta-QTL for GY and GPC detection was carried out using three inter-connected doubled haploid populations grown in a large multi-environment trial network, identifying several genomic regions having GY and GPC [37]. Among them, they found 2A and 2D chromosomes carrying important QTLs, suggesting that genomic regions close to GS2 genes are involved in GPC control.

\subsection{GOGAT Allelic Variants and Relationship with GPC}

Along with glutamine synthetase, glutamate synthase (GOGAT) forms an enzymatic complex considered to be one of the bottlenecks of the early stages of nitrogen metabolism, in particular as regards the absorption, assimilation, and amelioration of ammonia nitrogen in the plant. As previously reported [26,27], GOGAT genes have a complex intronic-exon structure: $F d$-GOGAT is comprised of 33 exons and has a size of about $15 \mathrm{~kb}$, while NADH-GOGAT is comprised of 22 exons separated by 21 introns and has a size of about $10 \mathrm{~kb}$. In order to find polymorphisms more easily in such long sequences, Fd-GOGAT and NADH-GOGAT genes were screened via an EcoTILLING approach. The different combinations of specific genomic primers (A and B) reported in Table S2 were amplified in the genotypes of the collection and analyzed for the presence of polymorphisms.

In this work, each combination was amplified as reported in the Materials and Methods section, and SNPs and indels polymorphisms were determined by duplex ether formation and digestion with 
the CelI enzyme. The duplex was obtained from each single genotype in the collection and the cv Svevo was used as control.

Digestion probes of different primer combinations for $F d-G O G A T$ genes allowed the identification of six SNPs polymorphism. Out of the six SNPs found, three were located in intronic regions (Introns 5, 10 and 31), and three were located in the exon region (Exons 6, 31 and 32). None of them determined a change in aminoacidic predicted sequences.

With the aim of determining the association between SNP markers found in Fd-GOGAT genes and the protein content of the caryopsis, regression analysis was conducted between the SNPs markers and the percentages of grain protein of the trials previously described. As reported in Table 3, the six SNPs identified three allelic variants for both Fd-GOGAT-A2 and Fd-GOGAT-B2 genes, named as a, b, and c allelic variants, respectively. Out of the three identified variants in the $F d$-GOGAT- $A 2$ gene, the $F d-G O G A T-A 2 a$ allelic variant showed a highly significant correlation with GPC. This polymorphism was a C/T transition, significant at $p \geq 0.001$ in all three environments. Phenotypic variation ranged from 6.9 to $14.6 \%$ in Valenzano 2010, suggesting its potential effect on GPC. On the other hand, none of the three allelic variants identified for Fd-GOGAT-B2 showed any correlation with GPC.

Table 3. Regression analysis between Fd-GOGAT allelic variants and GPC $\left(\% \mathrm{DW}^{-1}\right)$ in a tetraploid wheat collection evaluated in three different environments.

\begin{tabular}{|c|c|c|c|c|c|c|c|c|c|c|c|}
\hline \multirow{2}{*}{ Gene } & \multirow{2}{*}{ Allele } & \multirow{2}{*}{ Frequency } & \multicolumn{9}{|c|}{ Environments } \\
\hline & & & $-\log _{10}(p)$ & Effect & $R^{2}$ & $-\log _{10}(p)$ & Effect & $R^{2}$ & $-\log _{10}(p)$ & Effect & $R^{2}$ \\
\hline Fd-GOGAT-A2a & $\mathrm{C} / \mathrm{T}$ & 204-17 & $4.1^{* * *}$ & -1.47 & 6.9 & $6.7^{* * *}$ & -2.48 & 11.7 & $8.4^{* * *}$ & -3.05 & 14.6 \\
\hline$F d-G O G A T-A 2 b$ & $\mathrm{C} / \mathrm{T}$ & 115-99 & 0.2 & -0.09 & 0.1 & 0.0 & -0.02 & 0.0 & 0.2 & -0.14 & 0.1 \\
\hline$F d-G O G A T-A 2 c$ & $\mathrm{~A} / \mathrm{G}$ & $100-117$ & 0.3 & 0.12 & 0.2 & 0.0 & 0.02 & 0.0 & 0.2 & 0.13 & 0.1 \\
\hline$F d-G O G A T-B 2 c$ & $\mathrm{~A} / \mathrm{G}$ & 117-101 & 0.3 & -0.15 & 0.3 & 0.0 & 0.00 & 0.0 & 0.2 & -0.14 & 0.1 \\
\hline
\end{tabular}

* and ${ }^{* * *}=$ significant at $p \geq 0.05$ and $p \geq 0.001$, respectively, using the Bonferroni threshold (P/18) to control for multiple testing. $R^{2}=$ Phenotypic variation $(\%)$.

The same approach was followed in order to find out polymorphisms in NADH-GOGAT genes. A very similar scenario was detected for this gene: six different SNPs were detected in the screened genotypes, and specifically three SNPs for each genome resulting in three allelic variants for each homoeologous gene, named as $\mathrm{a}, \mathrm{b}$ and $\mathrm{c}$ allelic variants, respectively (Table 4 ). The results of regression analysis showed that, out of the three allelic variants for NADH-GOGAT-A3, only the T/G transversion, identified as the NADH-GOGAT-A3b allelic variant, showed a very high and significant association at $p \geq 0.001$ with GPC in the three considered environments. Phenotypic variation ranged from 7.0 to $11.1 \%$ in Valenzano 2010. NADH-GOGAT-A3a, a C/T transition, was found to be significantly associated in one environment only, Foggia 2009, at $p \geq 0.05$ with a phenotypic variation of $4.4 \%$.

As found in the NADH-GOGAT-A3 gene, the 3B homoeologous gene showed three allelic variants, identified as $a, b$, and $c$ and corresponding to a $G / T$ transversion, and $C / T$ and $A / G$ transitions, respectively. None of them showed a strong correlation nor a phenotypic effect as the NADH-GOGAT-A3b allelic variant, but two of them, NADH-GOGAT-B3a and NADH-GOGAT-B3c, had a significant association at $p \geq 0.05$ with GPC in the Foggia 2009 environment only, with an $R^{2}$ of $4.6 \%$ and $4.2 \%$, respectively.

Gene expression and post-transcriptional modification have a great effect on enzyme activity. However, mutations located both in exonic and intronic regions can affect gene expression levels. Insertion, deletions, and point mutations (single nucleotide polymorphisms) in introns can, for instance, introduce novel splice sites, activate novel promoters, or introduce/eliminate enhancer activity. 
A recent work of Zeng et al. [38] showed how a single nucleotide polymorphism, leading to an aminoacid substitution in rice $F d-G O G A T$ genes, resulted in an increased GPC, confirming its important role as a potential candidate in NUE improvement.

Table 4. Regression analysis between NADH-GOGAT allelic variants and GPC (\% DW $\left.{ }^{-1}\right)$ in a tetraploid wheat collection evaluated in three different environments.

\begin{tabular}{|c|c|c|c|c|c|c|c|c|c|c|c|}
\hline \multirow{3}{*}{ Gene } & \multirow{3}{*}{ Allele } & \multirow{3}{*}{ Frequency } & \multicolumn{9}{|c|}{ Environments } \\
\hline & & & \multicolumn{3}{|c|}{ Foggia 2009} & \multicolumn{3}{|c|}{ Valenzano 2009} & \multicolumn{3}{|c|}{ Valenzano 2010} \\
\hline & & & $-\log _{10}(p)$ & Effect & $R^{2}$ & $-\log _{10}(p)$ & Effect & $R^{2}$ & $-\log _{10}(p)$ & Effect & $R^{2}$ \\
\hline NADH-GOGAT-A3a & $a \mathrm{C} / \mathrm{T}$ & $145-70$ & $2.7 *$ & 0.68 & 4.4 & 1.3 & 0.58 & 1.9 & 1.6 & 0.73 & 2.4 \\
\hline NADH-GOGAT-A3b & $b \mathrm{G} / \mathrm{T}$ & $42-176$ & $6.1^{* * *}$ & -1.24 & 10.6 & $4.1^{* * *}$ & -1.36 & 7.0 & $6.4^{* * *}$ & -1.87 & 11.1 \\
\hline$N A D H-G O G A T-A 3 c$ & c $\mathrm{A} / \mathrm{G}$ & $111-103$ & 0.1 & -0.04 & 0.0 & 0.7 & -0.36 & 0.8 & 1.3 & -0.60 & 1.9 \\
\hline NADH-GOGAT-B3a & $\mathrm{G} / \mathrm{T}$ & $71-147$ & $2.8^{*}$ & -0.68 & 4.6 & 1.5 & -0.61 & 2.1 & 1.8 & -0.76 & 2.6 \\
\hline NADH-GOGAT-B3b & $b \mathrm{C} / \mathrm{T}$ & $115-103$ & 0.1 & -0.06 & 0.0 & 0.9 & -0.43 & 1.1 & 1.6 & -0.68 & 2.3 \\
\hline NADH-GOGAT-B3C & $\mathrm{A} / \mathrm{G}$ & $146-72$ & $2.6 *$ & 0.65 & 4.2 & 1.2 & 0.54 & 1.6 & 1.5 & 0.68 & 2.1 \\
\hline
\end{tabular}

$*$ and ${ }^{* * *}=$ significant at $p \geq 0.05$ and $p \geq 0.001$, respectively, using the Bonferroni threshold (P/18) to control for multiple testing. $R^{2}=$ Phenotypic variation $(\%)$.

The NADH-GOGAT gene was also identified as a major candidate gene for cereal NUE by a cross-genome ortho-meta QTL study of NUE [39]. QTL for GPC has also been reported on chromosome $3 \mathrm{AL}$ in in the homoeologous position of the NADH-GOGAT-3B gene [40] A proof of the central role of GOGAT genes was obtained in rice; the suppression of both GOGAT genes reduced yield per plant and thousand kernel weight, phenotypic indications of nitrogen starvation [41].

\section{Conclusions}

GPC is one of the most important wheat agronomic trait, in relation to both nutritional and technological properties. GPC is a typical quantitative trait, controlled by several genes and influenced by environmental factors. Different physiological processes also influence GPC, such as nitrogen uptake, assimilation, and remobilization to the grain. Several studies, carried out on different genetic materials, have reported the influence of the homoeologous chromosome groups 2 and 3 on GPC control. In 1990, important QTLs for GPC on group 2 chromosomes were firstly reported on durum wheat [42]. QTLs for GPC were also found on the short arms of homoeologous group 2 chromosomes in both bread and durum wheat $[40,43]$. Stable QTLs for GPC were also identified on 2A and 2B chromosomes in Canadian durum wheat populations [44]. Several authors have focused on deciphering GPC and NUE quantitative traits, and genetic diversity at candidate genes have lately been considered for this purpose. Both GS2 and Fd-GOGAT genes have been mapped in homoeologous group 2 chromosomes and have been found to co-localize with important QTLs for GPC in durum wheat $[10,27]$. Homoeologous group 3 was also found to be important for GPC control. An otho-Meta QTLs analysis for NUE identified NADH-GOGAT as one of the major effectors of NUE in wheat, rice, sorghum, and maize [39]. A QTL for GPC was also reported in the homoeologous position of chromosome 3AL [40]. Another important aspect to be considered in exploiting GPC and NUE is the importance of genotypic variation in gene and QTL expressions. Nigro et al. [12] showed how the genotype plays an important role in GS expression, especially at different $\mathrm{N}$ regimes. Previously, other authors have reported the importance of genotypic variation in NUE and final grain nitrogen content, determining that the genotype was one of the causes of variation in analyzed traits, after the N-rate and the growth stage [45].

The above data suggest that the genomic region surrounding GS2 and GOGAT genes are involved in grain protein accumulation, and the identification of new useful alleles for marker-assisted selection is valuable for breeding wheat varieties with improved agronomic performance and $\mathrm{N}$-use efficiency.

Supplementary Materials: The following are available online at www.mdpi.com/1424-2818/9/4/52/s1, Table S1: Genome specific primer combination for GS2 genes, Table S2: Genome specific primer combination for GOGAT genes, Table S3: List of tetraploid accession used in the study. 
Acknowledgments: This work was supported by Puglia Region, Italy, projects PSR "SAVEGRAIN" and "Intervento cofinanziato dal Fondo di Sviluppo e Coesione 2007-2013"-APQ Ricerca Regione Puglia "Programma regionale a sostegno della specializzazione intelligente e della sostenibilità sociale ed ambientale-FutureInResearch". The authors declare no conflicts of interest.

Author Contributions: Domenica Nigro, Agata Gadaleta and Antonio Blanco conceived and designed the experiments; Domenica Nigro, Stefania Fortunato and Stefania Lucia Giove performed the experiments; Giacomo Mangini, Ines Yacoubi and Antonio Blanco analyzed the data; Domenica Nigro, Rosanna Simeone and Agata Gadaleta wrote the paper.

Conflicts of Interest: The authors declare no conflict of interest.

\section{References}

1. Lawlor, D.W. Carbon and nitrogen assimilation in relation to yield: Mechanisms are the key to understanding production systems. J. Exp. Bot. 2002, 53, 789-799. [CrossRef]

2. Triboi, E.; Triboi-Blondel, A.M. Productivity and grain or seed composition: A new approach to an old problem. Eur. J. Agron. 2002, 16, 163-186. [CrossRef]

3. Lea, P.J.; Azevedo, R.A. Nitrogen use efficiency. 2. Amino acid metabolism. Ann. Appl. Biol. 2007, 151, 269-275. [CrossRef]

4. Hirel, B.; le Gouis, J.; Ney, B.; Gallais, A. The challenge of improving nitrogen use efficiency in crop plants: Towards a more central role for genetic variability and quantitative genetics within integrated approaches. J. Exp. Bot. 2007, 58, 2369-2387. [CrossRef] [PubMed]

5. Obara, M.; Sato, T.; Sasaki, S.; Kashiba, K.; Nagano, A.; Nakamura, I.; Ebitani, T.; Yano, M.; Yamaya, T. Identification and characterization of a QTL on chromosome 2 for cytosolic glutamines ynthetase content and panicle number in rice. Theor. Appl. Genet. 2004, 110, 1-11. [CrossRef] [PubMed]

6. Swarbreck, S.M.; Defoin-Platel, M.; Hindle, M.; Saqi, M.; Habash, D.Z. New perspectives on glutamine synthetase in grasses. J. Exp. Bot. 2011, 62, 1511-1522. [CrossRef] [PubMed]

7. Bernard, S.M.; Møller, A.L.B.; Dionisio, G.; Kichey, T.; Jahn, T.P.; Dubois, F.; Baudo, M.; Lopes, M.S.; Tercé-Laforgue, T.; Foyer, C.H.; et al. Gene expression, cellular localization and function of glutamine synthetase isozymes in wheat (Triticum aestivum L.). Plant. Mol. Biol. 2008, 67, 89-105. [CrossRef] [PubMed]

8. Thomsen, H.C.; Eriksson, D.; Moller, I.S.; Schjoerring, J.K. Cytosolic glutamine synthetase: A target for improvement of crop nitrogen use efficiency? Trends Plant. Sci. 2014, 19, 656-663. [CrossRef] [PubMed]

9. Habash, D.Z.; Bernard, S.; Schondelmaier, J.; Weyen, J.; Quarrie, S.A. The genetics of nitrogenuse in hexaploid wheat:N utilisation, development and yield. Theor. Appl. Genet. 2007, 114, 403-419. [CrossRef] [PubMed]

10. Gadaleta, A.; Nigro, D.; Giancaspro, A.; Blanco, A. The glutamine synthetase (GS2) genes in relation to grain protein content of durum wheat. Funct. Integr. Genom. 2011, 11, 665-670. [CrossRef] [PubMed]

11. Gadaleta, A.; Nigro, D.; Marcotuli, I.; Giancaspro, A.; Giove, S.L.; Blanco, A. Isolation and characterization of cytosolic glutamine synthetase (GSe) genes and association with grain protein content in durum wheat. Crop Pasture Sci. 2014, 65, 38-45. [CrossRef]

12. Nigro, D.; Fortunato, S.; Giove, S.L.; Paradiso, A.; Gu, Y.Q.; Blanco, A.; de Pinto, M.C.; Gadaleta, A. Glutamine synthetase in Durum Wheat: Genotypic Variation and Relationship with Grain Protein Content. Front. Plant Sci. 2016, 7, 971. [CrossRef] [PubMed]

13. Forde, B.G.; Lea, P.J. Glutamate in plants: Metabolism, regulation, and signalling. J. Exp. Bot. 2007, 58, 2339-2358. [CrossRef] [PubMed]

14. Cren, M.; Hirel, B. Glutamine Synthetase in Higher Plants Regulation of Gene and Protein Expression from the Organ to the Cell. Plant Cell Physiol. 1999, 40, 1187-1193. [CrossRef]

15. Tabuchi, M.; Abiko, T.; Yamaya, T. Assimilation of ammonium ions and reutilization of nitrogen in rice. J. Exp. Bot. 2007, 58, 2319-2327. [CrossRef] [PubMed]

16. Cánovas, F.M.; Avila, C.; Cantón, F.R.; Cañas, R.A.; de la Torre, F. Ammonium assimilation and amino acid metabolism in conifers. J. Exp. Bot. 2007, 58, 2307-2318. [CrossRef]

17. Leegood, R.C.; Lea, P.J.; Adcock, M.D.; Hausler, R.E. The regulation and control of photorespiration. J. Exp. Bot. 1995, 46, 1397-1414. [CrossRef] 
18. Ferrario-Méry, S.; Hodges, M.; Hirel, B.; Foyer, C.H. Photorespiration dependent increases in phosphoenolpyruvate carboxylase, isocitrate dehydrogenase and glutamate dehydrogenase in transformed tobacco plants deficient in ferredoxin-dependent glutamine-alpha-ketoglutarate aminotransferase. Planta 2002, 214, 877-888. [CrossRef] [PubMed]

19. Ferrario-Méry, S.; Valadier, M.H.; Godefroy, N.; Miallier, D.; Hirel, B.; Foyer, C.H.; Suzuki, A. Diurnal changes in ammonia assimilation in transformed tobacco plants expressing ferredoxin-dependent glutamate synthase mRNA in the antisense orientation. Plant Sci. 2002, 163, 59-67. [CrossRef]

20. Lancien, M.; Martin, M.; Hsieh, M.H.; Leustek, T.; Goodman, H.; Coruzzi, G.M. Arabidopsis glt1-T mutant defines a role for NADH-GOGAT in the non-photorespiratory ammonium assimilatory pathway. Plant J. 2002, 29, 347-358. [CrossRef] [PubMed]

21. Sakakibara, H.; Kawabata, S.; Takahashi, H.; Hase, T.; Sugiyama, T. Molecular cloning of the family of glutamine synthetase genes from maize: Expression of genes for glutamine synthetase and ferredoxin-dependent glutamate synthase in photosynthetic and non-photosynthetic tissues. Plant Cell Physiol. 1992, 33, 49-58.

22. Zehnacker, C.; Becker, T.W.; Suzuki, A.; Carrayol, E.; Caboche, M.; Hirel, B. Purification and properties of tobacco ferredoxin-dependent glutamate synthase, and isolation of corresponding cDNA clones. Light-inducibility and organspecificity of gene transcription and protein expression. Planta 1992, 187, 266-274. [CrossRef] [PubMed]

23. Coschigano, K.T.; Melo-Oliveira, R.; Lim, J.; Coruzzi, G.M. Arabidopsis gls mutants and distinct Fd.-GOGAT genes: Implications for photorespiration and primary nitrogen assimilation. Plant Cell 1998, 10, 741-752. [CrossRef] [PubMed]

24. Avila, C.; Márquez, A.J.; Pajuelo, P.; Cannell, M.E.; Wallsgrove, R.M.; Forde, B.G. Cloning and sequence analysis of a cDNA for barley ferredoxin-dependent glutamate synthase and molecular analysis of photorespiratory mutants deficient in the enzyme. Planta 1993, 189, 475-483. [CrossRef] [PubMed]

25. Boisson, M.; Mondon, K.; Torney, V.; Nicot, N.; Laine, A.L.; Bahrman, N.; Gouy, A.; Daniel-Vedele, F.; Hirel, B.; Sourdille, P.; et al. Partial sequences of nitrogen metabolism genes in hexaploid wheat. Theor. Appl. Genet. 2005, 110, 932-940. [CrossRef] [PubMed]

26. Nigro, D.; Gu, Y.Q.; Huo, N.; Marcotuli, I.; Blanco, A.; Gadaleta, A.; Anderson, O.D. Structural analysis of the wheat genes encoding NADH-dependent glutamine-2-oxoglutarate amidotransferases genes and correlation with grain protein content. PLoS ONE 2013, 8, e73751. [CrossRef] [PubMed]

27. Nigro, D.; Blanco, A.; Anderson, O.D.; Gadaleta, A. Characterization of Ferredoxin-Dependent Glutamine-Oxoglutarate Amidotransferase (Fd-GOGAT) Genes and Their Relationship with Grain Protein Content QTL in Wheat. PLoS ONE 2014, 9, e103869. [CrossRef] [PubMed]

28. Sharp, P.J.; Kreis, M.; Shewry, P.R.; Gale, M.D. Location of b-amylase sequences in wheat and its relatives. Theoret. Appl. Genet. 1988, 75, 286-290. [CrossRef]

29. Freed, R.; Eisensmith, S.P.; Goetz, D.; Reicosky, D.; Smail, V.W.; Wolberg, P. MSTAT-C: A Microcomputer Program for the Design, Management, and Analysis of Agronomic Research Experiments; Michigan State University: East Lansing, MI, USA, 1991.

30. Laido, G.; Mangini, G.; Taranto, F.; Gadaleta, A.; Blanco, A.; Cattivelli, L.; de Vita, P. Genetic diversity and population structure of tetraploid wheats (Triticum turgidum L.) estimated by SSR, DArT and pedigree data. PLoS ONE 2013, 8, e67280. [CrossRef] [PubMed]

31. Marcotuli, I.; Houston, K.; Schwerdt, J.G.; Waugh, R.; Fincher, G.B.; Burton, R.A.; Gadaleta, A. Genetic diversity and genome wide association study of $\beta$-glucan content in tetraploid wheat grains. PLoS ONE 2016, 11, e0152590. [CrossRef] [PubMed]

32. Colasuonno, P.; Lozito, M.L.; Marcotuli, I.; Nigro, D.; Giancaspro, A.; Mangini, G.; Simeone, R. The carotenoid biosynthetic and catabolic genes in wheat and their association with yellow pigments. BMC Genom. 2017, 18, 122. [CrossRef] [PubMed]

33. Nigro, D.; Laddomada, B.; Mita, G.; Blanco, E.; Colasuonno, P.; Simeone, R.; Blanco, A. Genome-wide association mapping of phenolic acids in tetraploid wheats. J. Cereal Sci. 2017, 75, 25-34. [CrossRef]

34. Li, X.P.; Zhao, X.Q.; He, X.; Zhao, G.Y.; Li, B.; Liu, D.C.; Li, Z.S. Haplotype analysis of the genes encoding glutamine synthetase plastic isoforms and their association with nitrogen-use-and yield-related traits in bread wheat. New Phytol. 2011, 189, 449-458. [CrossRef] [PubMed] 
35. Guttieri, M.J.; Frels, K.; Regassa, T.; Waters, B.M.; Baenziger, P.S. Variation for nitrogen use efficiency traits in current and historical great plains hard winter wheat. Euphytica 2017, 213, 87. [CrossRef]

36. Fontaine, J.X.; Ravel, C.; Pageau, K.; Heumez, E.; Dubois, F.; Hirel, B.; Le Gouis, J. A quantitative genetic study for elucidating the contribution of glutamine synthetase, glutamate dehydrogenase and other nitrogen-related physiological traits to the agronomic performance of common wheat. Theor. Appl. Genet. 2009, 119, 645-662. [CrossRef] [PubMed]

37. Bogard, M.; Allard, V.; Martre, P.; Heumez, E.; Snape, J.W.; Orford, S.; Griffiths, S.; Gaju, O.; Foulkes, J.; Le Gouis, J. Identifying wheat genomic regions for improving grain protein concentration independently of grain yield using multiple inter-related populations. Mol. Breed. 2013, 31, 587. [CrossRef]

38. Zeng, D.D.; Qin, R.; Li, M.; Alamin, M.; Jin, X.L.; Liu, Y.; Shi, C.H. The ferredoxin-dependent glutamate synthase (OsFd-GOGAT) participates in leaf senescence and the nitrogen remobilization in rice. Mol. Genet. Genom. 2017, 292, 385. [CrossRef] [PubMed]

39. Quraishi, U.M.; Abrouk, M.; Murat, F.; Pont, C.; Foucrier, S.; Desmaizieres, G.; Confolent, C.; Riviere, N.; Charmet, G.; Paux, E.; et al. Cross-genome map based dissection of a nitrogen use efficiency ortho-meta QTL in bread wheat unravels concerted cereal genome evolution. Plant J. 2011, 65, 745-756. [CrossRef] [PubMed]

40. Blanco, A.; Mangini, G.; Giancaspro, A.; Giove, S.; Colasuonno, P.; Simeone, R.; Signorile, A.; de Vita, P.; Mastrangelo, A.M.; Cattivelli, L.; et al. Relationships between grain protein content and grain yield components through QTL analyses in a RIL population derived from two elite durum wheat cultivars. Mol. Breed. 2012, 30, 79-92. [CrossRef]

41. Lu, Y.; Luo, F.; Yang, M.; Li, X.; Lian, X. Suppression of glutamate synthase genes significantly affects carbon and nitrogen metabolism in rice (Oryza sativa L.). China Life Sci. 2011, 54, 651-663. [CrossRef] [PubMed]

42. Joppa, L.R.; Cantrell, R.G. Chromosomal location of genes for grain protein content of wild tetraploid wheat. Crop Sci. 1990, 30, 1059-1064. [CrossRef]

43. Prasad, M.; Varshney, R.K.; Kumar, A.; Balyan, H.S.; Sharma, P.C.; Edwards, K.J.; Gupta, P.K. A microsatellite marker associated with a QTL for grain protein content on chromosome arm 2DL of bread wheat. Theor. Appl. Genet. 1999, 99, 341-345. [CrossRef]

44. Suprayogi, Y.; Pozniak, C.J.; Clarke, F.R.; Clarke, J.M.; Knox, R.E.; Singh, A.K. Identification and validation of quantitative trait loci for grain protein concentration in adapted Canadian durum wheat populations. Theor. Appl. Genet. 2009, 119, 437-448. [CrossRef] [PubMed]

45. Barraclough, P.B.; Lopez-Bellido, R.; Hawkesford, M.J. Genotypic variation in the uptake, partitioning and remobilization of nitrogen during grain-filling in wheat. Field Crops Res. 2014, 156, 242-248. [CrossRef] [PubMed]

(C) 2017 by the authors. Licensee MDPI, Basel, Switzerland. This article is an open access article distributed under the terms and conditions of the Creative Commons Attribution (CC BY) license (http:/ / creativecommons.org/licenses/by/4.0/). 